\title{
PENINGKATAN KETAHANAN PANGAN MASA PANDEMI COVID- 19 DI NGROPOH KRANGGAN TEMANGGUNG
}

\author{
Victory Cindy Maylana ${ }^{1}$, Ari Prasetyo ${ }^{2}$, Syamsul Hadi $^{3}$ \\ ${ }^{1}$ Ilmu Akuntansi Fakultas Ekonomi dan Bisnis Universitas Sebelas Maret \\ ${ }^{2}$ Teknik Mesin Sekolah Vokasi Universitas Sebelas Maret \\ ${ }^{3}$ Teknik Mesin Fakultas Teknik Universitas Sebelas Maret
}

syamsulhadi@ft.uns.ac.id

\begin{abstract}
Abstrak
Awal tahun 2020 seluruh dunia digoncang dengan pandemi Covid-19 yang membuat kepanikan dimana-mana. Dampak dari pandemi Covid-19 telah mengganggu berbagai aspek kehidupan mulai dari kesehatan, sosial, ekonomi dan beragam lain sebagainya. Salah satu persoalan utamanya adalah berkenaan dengan ketahanan pangan yang saat ini menjadi sangat ramai dan menjadi perbincangan publik. Berdasarkan permasalahan tersebut, pengabdian pada masyarakat melalui kegiatan KKN UNS dilakukan dengan program kerja untuk meningkatkan ketahanan pangan berupa budidaya dan vertikultur, peningkatan peran embung Abimanyu dan program tambahan untuk mendukung ketahanan pangan di Desa Ngropoh, Kecamatan Kranggan, Kabupaten Temanggung. Hasil kegiatan pengabdian menunjukkan bahwa masyarakat mengalami peningkatan pemenuhan kebutuhan pangan sehari-hari serta dapat hidup dan beraktivitas dengan lebih sehat.
\end{abstract}

Kata Kunci : KKN, Covid-19, ketahanan pangan, vertikultur, embung Abimanyu

\begin{abstract}
In early 2020 the whole world was shaken by the Covid-19 pandemic, which caused panic everywhere. The impact of the Covid-19 pandemic has disrupted various aspects of life such as health, social, economic, etc. One of the main problems is food security, which is currently becoming a very active topic of conversation. Based on these problems, community service through UNS KKN activities is carried out with work programs to improve food security in the form of cultivation and viticulture, increase the role of the Abimanyu reservoir, and additional programs to support food security in Ngropoh Village, Kranggan District, Temanggung Regency. The results of community service activities show that the community has experienced an increase in fulfilling their daily food needs and can live and carry out activities more healthily
\end{abstract}

Keywords : KKN, Covid-19, food security, viticulture, Abimanyu reservoir

\section{PENDAHULUAN}

Covid-19 merupakan penyakit menular yang tengah menyebar dan sebanyak $90 \%$ negara di dunia telah menjadi korban. Organisasi kesehatan dunia (WHO) memberikan pernyataan bahwa status penularan virus corona dari varian virus yang dikenal dengan istilah Covid-19 telah menjadi status pandemi, karena dinilai bahwa wabah ini sudah 
sampai tingkat penyebaran dan keparahan yang mengkhawatirkan. Melalui Pembatasan Sosial Bersekala Besar (PSBB) yang dilakukan oleh pemerintah Indonesia, seperti hal adanya himbauan kepada masyarakat untuk melakukan pembatasan sosial misalnya dengan melakukan beragam aktivitas dirumah dan mengurangi kontak fisik.

Ketahanan pangan menjadi salah satu hal yang penting pada saat pandemi Covid 19 karena dapat mengakibatkan berbagai permasalahan di antaranya terganggunya produksi, distribusi, dan konsumsi kebutuhan pokok. Ketersediaan bahan pangan pada kondisi pandemi memegang peranan penting mengingat pangan merupakan kebutuhan dasar penduduk. Hal ini perlu menjadi perhatian mengingat pandemi Covid-19 berpengaruh pada krisis pangan jika tidak dikelola dengan baik. Di satu sisi, pandemi Covid-19 mendorong penerapan pembatasan sosial. Di sisi lain, kebutuhan pangan diperkirakan dikonsumsi dalam kuantitas yang sama meskipun aktivitas masyarakat lebih terbatas. Salah satu yang bisa dilakukan pada masa pandemi adalah dengan pertanian vertikultur. Karena dengan vertikultur maka produktifitas masyarakat tetap terjaga, hemat lahan, bisa dengan berbagai macam sayuran dan dapat dikolaborasikan dengan program lain (Setiawan dan Pasau, 2017; Santosa dkk, 2018; Hadi dkk, 2019; Wachdijono dkk, 2019; Hadi dkk, 2020; Irawati dkk, 2020; dan Prihatiningsih dkk, 2020)

Desa Ngropoh merupakan salah satu desa di wilayah Kecamatan Kranggan Kabupaten Temanggung dengan luas wilayah 479,184 Ha terdiri dari 12 dusun dengan 5 RW dan $30 \mathrm{RT}$, dengan jumlah penduduk 3.230 jiwa. Potensi perekonomian masyarakat desa ini cukup banyak, diantaranya pertanian, perkebunan durian, peternakan, industri rumah tangga dan potensi pariwisata. Potensi tersebut belum dikelola secara optimalkaena pengelolaan potensi tersebut masih dilakukan secara konvesional yaitu dengan menggunakan peralatan sederhana, manajemennya serta pemasarannya sederhana (Widyanto dkk, 2021).

Selain itu embung Abimanyu yang ada di daerah tersebut merupakan salah satu potensi pariwisata yang belum dioptimalkan karena hanya digunakan untuk penyimpanan air selama musim hujan dan pengairan lahan pertanian dan perkebunan di musim kemarau. Lingkungan sekitar embung bisa dimanfaatkan utuk kegiatan pariwisata karena memiliki panorama yang indah dan sudah disediakan fasilitas gedung serbaguna (Widyanto dkk, 2021). Cara kerja kehidupan di sekitar embung juga bisa menjadi potensi wisata edukasi (eduwisata) yang mengajarkan tentang pertanian dan pengelolaan wisata (Wibowo dkk, 2018).

Di tengah kondisi COVID-19 ini masyarakat desa Ngropoh sedang mengupayakan program ketahanan pangan. Hal ini diharapkan agar masyarakat dapat meningkatkan ketahanan pangan setiap keluarga dari rumah masing masing dengan media yang kecil dan portable, yang paling menguntungkan lainnya yaitu perawatannya yang mudah, sehingga pun masyarakat tidak perlu berbelanja ke pasar/ pusat perbelanjaan sehingga mereka terhindar dari bahaya penularan Covid-19.

Dengan demikian, Tim KKN UNS berupaya untuk mengambil peran dalam mengabdikan diri kepada warga Desa Ngropoh Kecamatan Kranggan melalui beberapa program kerjanya yang berwujud pembuatan budidaya dalam ember dan vertikultur tanam pangan.

\section{METODE}

Kegiatan KKN UNS dilaksanakan pada 12 Januari 2021 sampai dengan 25 Februari 2021 melalui delapan program kerja yang terbagi dalam 3 program besar yaitu; 1. Peningkatan ketahanan pangan dengan pembuatan budidaya ikan dalam ember, pembuatan vertikultur tanaman pangan, pendampingan perawatan budidaya dalam ember dan vertikultur; 2. Peningkatan potensi embung Abimanyu dengan kegiatan pengadaan peta desa wisata, penataan embung, pengadaan bibit ikan dan pembersihan embung, pembuatan tempat cuci tangan di embung Abimanyu, dan; 3. Program tambahan yang berupa peningkatan Pojok Baca, edukasi pola hidup sehat dan sosialiasi pembuatan hand sanitizer dan masker. Metode yang digunakan untuk melaksanakan pengabdian adalah identifikasi permasalahan dengan survey ke lapangan, diskusi dan penyusunan rencana kerja dengan masyarakat dan pembimbing, pelaksanaan rencana kerja dan evaluasi serta laporan.

\section{HASIL DAN PEMBAHASAN}

Berdasarkan permasalahan yang tertera pada pendahuluan, maka penulis memberikan peran

Lingkungan Hidup dan Kebencanaan 571 
dan kontribusi untuk menyelesaikan permasalahan tersebut secara responsif dan solutif.

\section{Pembuatan Budidaya Dalam Ember}

Budidaya dalam ember terbilang masuk urban farming, yakni metode pertanian dengan konsep berkebun di lahan terbatas. Hasilnya dapat dimanfaatkan untuk memenuhi kebutuhan pangan rumah tangga dan bisa dijual bila berlebih. Program urban farming budidaya dalam ember itu juga sangat cocok diterapkan lintas masyarakat, khususnya bagi mereka yang kesulitan memenuhi kebutuhan pangan secara mandiri selama pandemi Covid-19 dan memberi pengalaman baru. Budidaya dalam ember saat ini membudidayakan kangkung dan pembesaran ikan lele. Beberapa kelebihan dari budidaya dalam ember ini adalah dapat membudidayakan dua komoditas sekaligus yaitu ikan dan sayuran. Dalam hal ini komoditas ikan lele dan sayuran kangkung. Sehingga dapat memanen dua komoditas secara bersamaan atau bergantian. Selain itu budidaya ini dapat dilakukan dengan media yang kecil dan portable, yang paling menguntungkan lainnya yaitu perawatannya yang mudah.

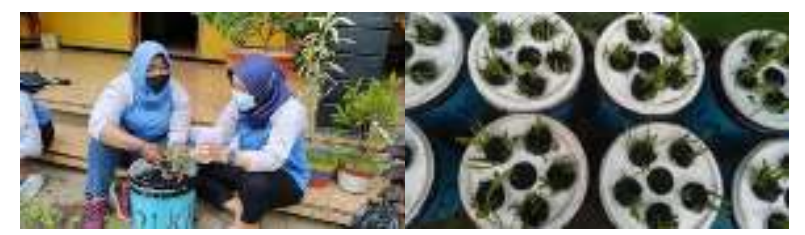

Gambar 1. Pembuatan Budidaya Dalam Ember

\section{Pembuatan Vertikultur Tanam Pangan}

Vertikultur merupakan teknik bercocok tanam diruang/lahan sempit dengan memanfaatkan bidang vertikal sebagai tempat bercocok tanam yang dilakukan secara bertingkat. Tujuan vertikultur adalah memanfaatkan lahan yang sempit secara optimal. Vertikultur ini memiliki beberapa kelebihan diantaranya : Efisiensi dalam penggunaan lahan; Penghematan pemakaian pupuk dan pestisida; Dapat dipindahkan dengan mudah karena tanaman diletakkan dalam wadah tertentu; Mudah dalam hal monitoring/pemeliharaan tanaman. Sistem budidaya tanaman yang dilakukan secara vertikal atau bertingkat dapat dilakukan dalam ruangan maupun luar ruangan. Selain itu dengan vertikultur tanam pangan, masyarakat tidak perlu berbelanja sayuran ke pasar/ pusat perbelanjaan sehingga mereka terhindar dari bahaya penularan Covid-19.

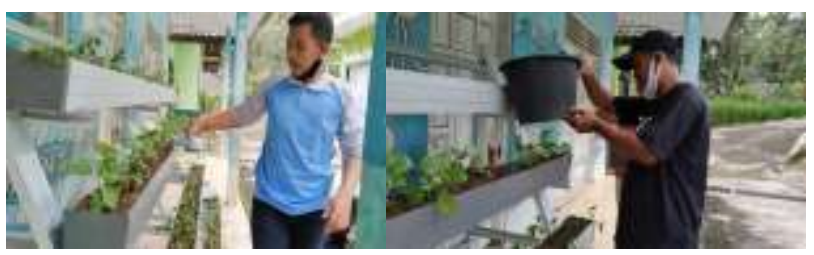

Gambar 2. Pembuatan Vertikultur Tanam Pangan

\section{Pendampingan Perawatan Budidaya Dalam Ember Dan Vertikultur}

Perawatan Budidaya dalam ember dan vertikultur tanam pangan memang tergolong mudah, namun bukan berarti hal ini bisa disepelekan.

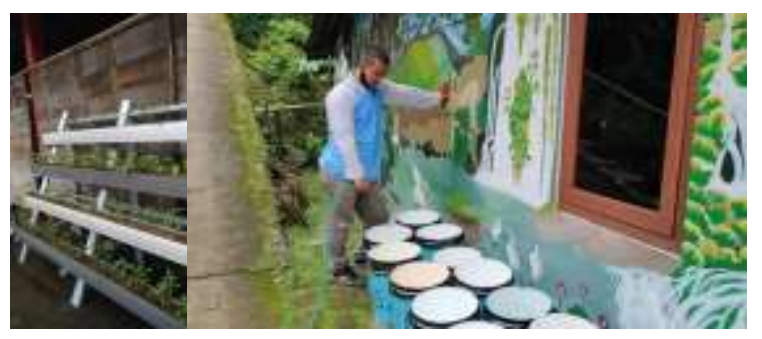

Gambar 3. Pendampingan Perawatan Budidaya Dalam Ember Dan Vertikultur

Ada beberapa langkah yang harus dilakukan untuk merawat budidaya dalam ember yaitu pemberian makan yang secukupnya, buang daun dan batang kangkung yang berwarna kuning dan penggantian air 10-14 hari sekali. Selain itu untuk vertikultur tanam pangan juga harus diperhatikan cara merawatnya seperti penyiraman secara berkala dan penggantian media tanam bila diperlukan.

\section{Pengadaan Peta Desa Wisata}

Program kerja yang berupa pengadaan peta desa wisata merupakan sarana agar masyarakat / wisatawan dapat mengetahui posisi atau letak tempat wisata yang ada di desa Ngropoh. Hal ini dianggap penting dikarenakan Desa Ngropoh merupakan salah satu desa yang memiliki beberapa tempat wisata yang wajib dikunjungi oleh wisatawan. Faktor pendukung kegiatan ini yaitu

$$
\text { Lingkungan Hidup dan Kebencanaan } 572
$$


belum adanya peta desa wisata untuk memudahkan para wisatawan mencari lokasi wisata di desa Ngropoh, sedangkan faktor penghambat kegiatan ini adalah sulitnya memberikan petunjuk yang jelas dan detail dalam pembuatan peta desa wisata. Hasil yang dicapai oleh proker ini ialah menambah sarana dalam bidang pariwisata di desa Ngropoh. Sedangkan tindak lanjut dari program kerja ini adalah penerapan penggunaan peta desa wisata di kemudian hari, dan rencana memperbanyak peta desa wisata disetiap titik masuk desa Ngropoh. Partisipasi masyarakat di Desa Ngropoh sangat baik. Saat pembuatan peta desa wisata, warga membantu dalam hal pencarian tempat wisata dan arah menuju lokasi tersebut.

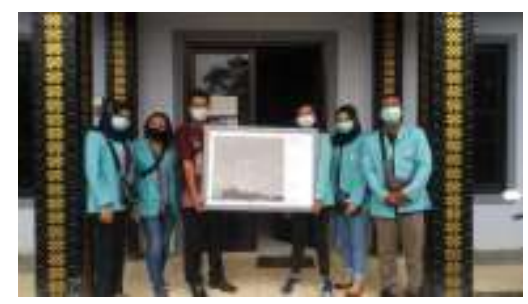

Gambar 4. Pembuatan Peta Desa Wisata

\section{Penataan Embung}

Program kerja yang berupa kerjasama penataan embung ini merupakan program kerja yag diusung untuk memulihkan kembali salah satu tempat wisata di Desa Ngropoh yaitu Embung Abimanyu, akibat adanya pandemi covid-19 ini yang pasti sangat berpengaruh terhadap bidang pariwisata. Kerjasama penataan embung ini ditujukan untuk memperbaiki sarana dan prasana yang rusak serta himbauan himbauan berwisata di lokasi tersebut.Faktor pendukung kegiatan ini yaitu mulai rusaknya sarana dan prasana yang ada serta tidak adanya himbauan untuk menata kelestarian alam yang ada di Embung, adapun faktor penghambat kegiatan ini hilangnya kursi kursi yang sudah dibuat untuk memperbaiki sarana dan prasana yang ada.

Hasil yang dicapai oleh proker ini ialah memperbaiki sarana dan prasarana serta menata kembali tempat wisata tersebut yang dilengkapi dengan adanya protokol kesehatan. Sedangkan tindak lanjut dari program kerja ini adalah meningkatkan wisatawan yang berkunjung ke tempat wisata tersebut. Partisipasi masyarakat (pengurus desa wisata dan kepala desa) di Desa Ngropoh sangat baik. Mereka membantu memberikan ide ide untuk menjalakan program kerja ini agar menjadi semakin baik dikemudian hari.

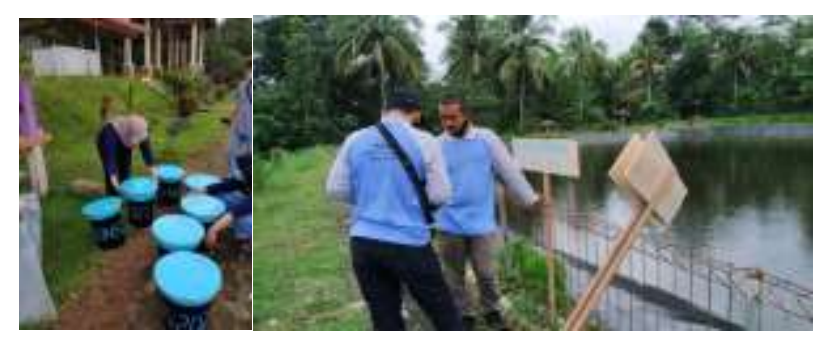

Gambar 5. Penataan Embung Abimanyu

\section{Pengadaan Bibit Ikan dan Pembersihan Embung}

Program kerja yang berupa pengadaan bibit ikan dan pembersihan embung ini merupakan salah satu langkah untuk mengembangkan kembali potensi Embung Abimanyu. Dengan adanya pengadaan bibit ikan ini diharapkan dapat digunakan di masa yang akan datang untuk acara lomba pancing yang pernah diadakan sebelumnya. Namun akibat pandemi Covid-19 ini maka ikan ikan diambil oleh pihak yang tidak bertanggung jawab. Faktor pendukung kegiatan ini yaitu berkurangnya ikan ikan di Embung akibat pengambilan secara ilegal oleh pihak-pihak yang tidak bertangung jawab, adapun faktor penghambat kegiatan kurangnya himbauan untuk larangan memancing di Embung.

Hasil yang dicapai oleh proker ini ialah pengadaam bibit ikan di embung. Sedangkan tindak lanjut dari program kerja ini adalah di masa yang akan datang dapat dimanfaatkan sebagai acara lomba memancing tahunan yang dapat menarik para wisatawan. Partisipasi masyarakat (kepala desa) di Desa Ngropoh sangat baik. Kepala desa dan warga sekitar embung sangat mendukung program kerja ini yang juga dapat meningkatkan minat wisatawan di masa yang akan datang. 


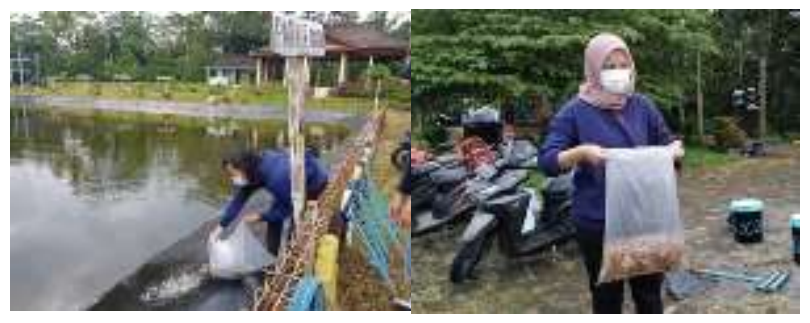

Gambar 6. Pengadaan Bibit Ikan dan Pembersihan Embung Abimanyu

\section{Pembuatan Tempat Cuci Tangan di Embung Abimanyu}

Kebiasaan mencuci tangan dengan sabun menjadi bagian penting dalam rantai pertahanan kesehatan, terutama di masa pandemi seperti saat ini. Walaupun terkesan sederhana, kebiasaan mencuci tangan dengan sabun merupakan investasi kesehatan jangka panjang yang dapat mengurangi penularan penyakit. Dengan adanya protokol kesehatan, hal ini juga dapat mendongkrak datang nya wisatawan untuk berkunjung. Faktor pendukung kegiatan ini yaitu belum adanya penerapan protokol kesehatan di tempat wisata Embung Abimanyu, sedangkan faktor penghambat kegiatan ini masih ada beberapa pengunjung yang belum menerapkan protokol kesehatan meski sudah disiapkan tempat cuci tangan dan handsanitizer.
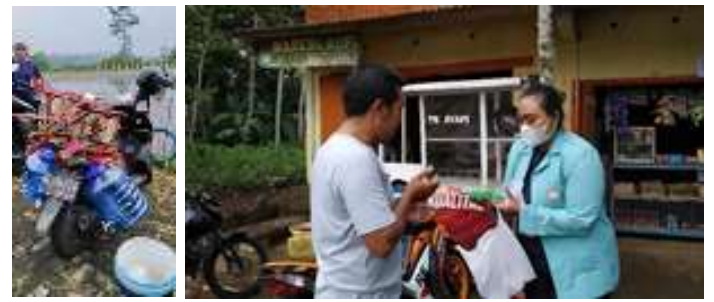

Gambar 7. Pendampingan Peningkatan Peduli Kesehatan di Tempat Wisata

Hasil yang dicapai oleh proker ini ialah meningkatnya pengetahuan, pemahaman, dan kesadaran warga yang lebih tinggi untuk menerapkan protokol kesehatan di tempat wisata. Sedangkan tindak lanjut dari program kerja ini adalah dapat meningatkan datangnya wisatawan ke tempat wisata yang sudah menerapkan protokol kesehatan. Partisipasi masyarakat (pengurus desa wisata dan penjual di tempat wisata) di Desa Ngropoh sangat baik, mereka sangat mendukung adanya program kerja ini untuk menunjang penerapan protokol Kesehatan

\section{Pojok baca}

Program kerja yang berupa pojok baca ini merupakan salah satu langkah untuk mengembangkan kembali suatu edukasi mengenai pentingnya membaca dan meningkatkan kreativitas secara efektif dan efisien untuk membangun SDM yang cerdas dan kreatif. Selain itu adanya perpustakaan desa yang tidak berfungsi dengan baik sehingga menjadi salah satu alasan program ini disusun. Faktor pendukung kegiatan ini yaitu kurang berfungsinya perpustakaan desa dengan baik. Adapun faktor penghambat kegiatan ini masih di masa pandemi dan perpustakaan desa sedang dialihkan menjadi sarana belajar taman kanak kanak

Hasil yang dicapai oleh proker ini ialah pembersihan perpustakaan desa dan perwujudan pojok baca. Sedangkan tindak lanjut dari program kerja ini adalah di masa yang akan datang dapat dimanfaatkan sebagai pojok baca secara aktif. Partisipasi masyarakat (kepala desa dan pengurus perpustakaan desa) di Desa Ngropoh sangat baik. Kepala desa dan pengurus perpustakaan sangat mendukung program kerja ini yang juga dapat meningkatkan minat membaca warga desa dan pelajar di masa yang akan datang

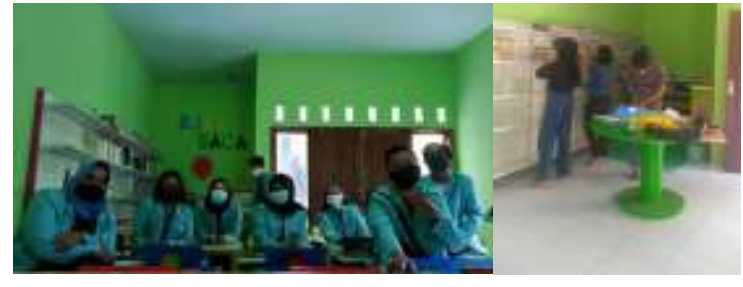

Gambar 8. Peningkatan Fasilitas Pojok Baca

\section{Edukasi Pola Hidup Sehat}

Pola Hidup Bersih dan Sehat adalah semua perilaku kesehatan yang dilakukan karena kesadaran pribadi sehingga keluarga dan seluruh anggotanya mampu menolong diri sendiri pada bidang kesehatan serta memiliki peran aktif dalam aktivitas masyarakat. Program kerja yang berupa edukasi tentang COVID-19 dan pola perilaku hidup bersih dan sehat di masa new normal ini merupakan suatu sarana sosialisai daring dalam meningkatkan Lingkungan Hidup dan Kebencanaan 574 
pemahaman dan pengetahuan mengenai urgensi untuk menjaga diri dan sesama dari COVID-19 melalui penerapkan perilaku hidup bersih dan sehat. Latar belakang dilaksanakannya program ini adalah masih kurangnya pemahaman informasi yang valid tentang COVID-19 dan pola perilaku hidup bersih dan sehat di masa new normal oleh warga Desa Ngropoh. Faktor pendukung kegiatan ini yaitu kurangnya pemahaman dan pengetahuan mengenai urgensi untuk menjaga diri dan sesama dari COVID-19 melalui penerapkan perilaku hidup bersih dan sehat, dan faktor penghambat kegiatan ini sulitnya penentuan waktu pelaksanaan pembagian materi di grup disebabkan karena para ibu ibu mempunyai kesibukan lainnya.

Hasil yang dicapai oleh proker ini ialah meningkatnya pengetahuan, pemahaman, dan kesadaran warga yang lebih tinggi untuk menerapkan protokol kesehatan dalam kehidupan sehari-hari khususnya di masa COVID- 19. Sedangkan tindak lanjut dari program kerja ini adalah penerapan pola hidup bersih dan sehat di setiap rumah warga dengan adanya tempat cuci tangan dan penerapan memakai masker. Partisipasi masyarakat (ibu ibu PKK) di Desa Ngropoh sangat baik. Saat materi edukasi dibagikan di grup PKK, para ibu aktif untuk bertanya apabila terdapat ketidakpahaman dalam penjelasan materi.
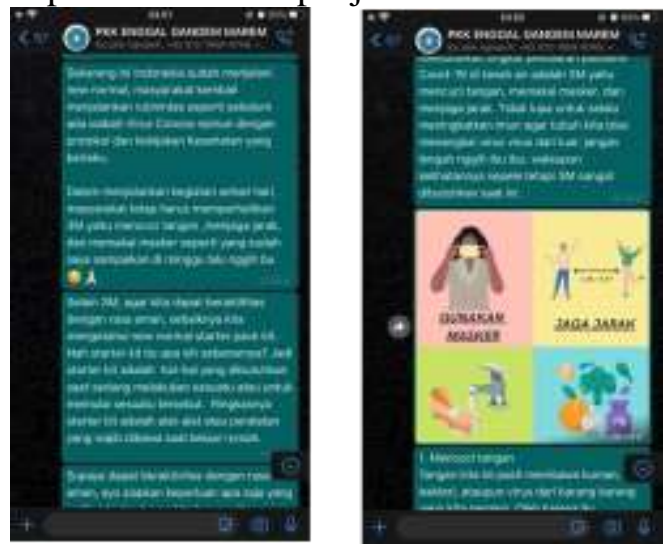

Gambar 9. Edukasi Pola Hidup Sehat Melalui Social Media

\section{Sosialiasi Pembuatan Hand Sanitizer dan Masker}

Penerapan protokol kesehatan harus menjadi kesadaran pribadi setiap warga khususnya dalam menjalankan aktivitas setiap harinya. Program kerja yang berupa sosialisasi pembuatan hand sanitizer dan masker ini merupakan suatu sarana sosialisai dalam meningkatkan pemahaman dan pengetahuan mengenai cara pembuatan handsanitizer dan masker dengan mudah untuk menerapkan protokol kesehatan di kehidupan sehari hari. Faktor pendukung kegiatan ini yaitu kurangnya pemahaman masyarakat mengenai cara membuat masker dan handsanitizer, adapun faktor penghambat kegiatan ini tidak hadirnya semua peserta dalam sosialisasi pembuatan hand sanitizer dan masker

Hasil yang dicapai oleh proker ini ialah meningkatkan pemahaman masyarakat dalam pembuatan handsanitizer dan masker. Sedangkan tindak lanjut dari program kerja ini adalah masyarakat dapat membuat handsanitizer dan masker sendiri di rumah. Partisipasi masyarakat (ibu-ibu PKK) di Desa Ngropoh sangat baik. Mereka memperhatikan setiap proses pembuatan handsanitizer dan masker dan bertanya jika ada ada yang belum jelas.

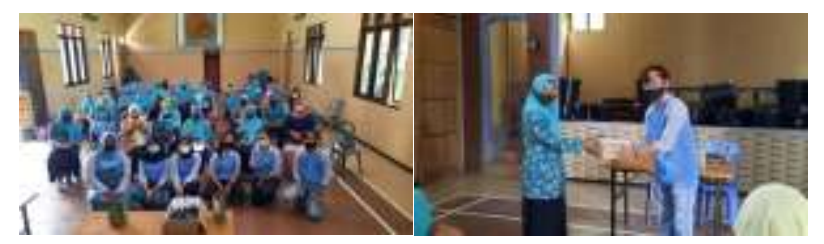

Gambar 10. Pendampingan dan Sosialisasi Pembuatan Hand Sanitizer dan Masker

\section{KESIMPULAN}

Pembuatan budidaya dalam ember dan vertikultur tanam pangan merupakan salah sau langkah strategis yang diambil untuk meningkatkan ketahanan angan masyarakat di tengah situasi pandemi Covid-19 ini sehingga menjadi langkah solutif dan efektif untuk meningkatkan ketahanan pangan keluarga dan masyarakat Desa Ngropoh untuk tetap aman serta terpenuhi kebutuhannya di situasi yang sulit ini. Di samping itu peningkatan peran embung Abimanyu untuk ketahanan pangan masyarakat juga berjalan baik. Masyarakat masih bisa memanfaatkan media tanam kembali setelah masa panen selesai sehingga menjadi program yang mengandung keberlanjutan di masa yang akan datang.

Lingkungan Hidup dan Kebencanaan 575 


\section{UCAPAN TERIMAKASIH}

Ucapan terima kasih dihaturkan kepada Lembaga Penelitian dan Pengabdian kepada Masyarakat Universitas Sebelas Maret (LPPM UNS) yang telah memberikan kesempatan dan dana untuk mendukung kegiatan KKN ini, Kepala Desa Ngropoh yang telah memberikan izin dan dukungan, serta seluruh warga Desa Ngropoh, Kecamatan Kranggan, Kabupaten Temanggung yang telah memberikan tanggapan yang baik dan antusiasme yang luar biasa.

Ucapan terimakasih juga disampaikan kepada tim yang telah melaksanakan kegiatan KKN yaitu Victory Cindy Maylana, Lintangsari Susanto Putri, Bima Megantyas Saputra, Dhoni Prastowo, Priska Erlyn Oktaningrum, Gladia Chandra Puspita, Galih Joko Puspito, dan Sarah Astita.

\section{REFERENSI}

Hadi, S., Ariawan, D., dan Arifin, Z., 2019, Pengembangan Desa melalui Optimalisasi Literasi, Pariwisata, Kesehatan, dan Sosial di Kecamatan Riung, Ngada, NTT, Jurnal SEMAR Vol. 8 No. 2, hal. $39-48$

Hadi, S., Wibowo, Triyono, J., Rujunia, L. O., dan Nasrianto, L. O., 2020, Peningkatan Potensi Wisata Desa Waginopo dengn Mengoptimalkan Sumber Daya Melalui Program Ekonomi Kreatif, Jurnal SEMAR Vol. 9 No. 1, hal. 36 - 47.

Irawati, N, dan Asriyana, 2020, Pemberdayaan Kelompok Masyarakat Pesisir melalui Budi Daya Rumput Laut Metode Vertikultur di Kawasan Perdesaan Tumbuh Lestari Desa Rambu Rambu, Kabupaten Konawe Selatan, Agrokreatif November 2020, Vol 6 (3): 239-248

Prihatiningsih, N., Minarni, E. W., dan
Nurtiati, 2020, Prihatiningsih_Sayuran Organik Sistem Vertikultur Aquaponik sebagai Pemanfaatan lahan Pekarangan, Dimas Budi-Jurnal Pengabdian kepada Masyarakat, Vol.4, No. 1, pp. 11-19

Santosa, S., Rohmanugraha, D., Antoro, Y. T., Nurjanah, T. R., Wardani, E., Narendra JHR, Istaqim L M, dan Hidayah, N., 2018, Optimalisasi Pemanfaatan Pekarangan Rumah dengan Sistem Vertikultur dari Limbah Plastik Sebagai Upaya Mendukung Indonesia Bebas Sampah dan Mewujudkan Ketahanan Pangan Keluarga di Dukuh Baturan Kec. Gantiwarno Kab. Klaten, APLIKASIA: Jurnal Aplikasi Ilmu-ilmu Agama Volume 18, Nomor 2, 2018 | Page: 127-134

Setiawan, K., dan Pasau, P., 2017, IbM Pemberdayaan Anak Panti Asuhan, E-DIMAS, 8(2), 227-235

Suharyanto, H., 2011, Ketahanan Pangan, Jurnal Sosial Humaniora Vol 4 No 2, hal. 186-194.

Wachdijono, Wahyuni, S., dan Trisnaningsih, U., 2019, Sosialisasi Urban Farming Melalui Budidaya Tanaman Sayuran Secara Vertukultur dan Hidroponik di Kelurahan Kalijaga, Kecamatan Harjamukti, Kota Cirebon, Jurnal Qardhul Hasan; Media Pengabdian kepada Masyarakat Volume 5 Nomor 2, pp 90-93

Wibowo, P., Roziana, F., Hapsari, R. D., dan Eva, N. K., 2018, Media Digital untuk Pengembangan Pariwisata Embung Banyu Lumut, SENADIMAS, pp. 493-499.

Widyanto, A. A., Febriyanto, W., , Binangkit, R. P, Larasati, R. D., Nurachman, R., dan Amalina, P. N., 2021, PPMT untuk Pengembangan Desa Wisata Embung Abimanyu di Desa Ngropoh Temanggung, Jurnal Abdimas PHB $\begin{array}{llll}\text { Vol.4 No.1 } & \text { 67-73 }\end{array}$ 